\title{
Education for Agrarian Resource Management Through Agrarian Citizenship Movement in Rural Areas
}

\author{
Triana Rejekiningsih ${ }^{1}$, Triyanto, Itok Dwi Kurniawan ${ }^{1}$ \\ ${ }^{1}$ Sebelas Maret University \\ Email triana_rizq@staff.uns.ac.id
}

\begin{abstract}
In countries with agrarian potentials such as Indonesia, the villages play a very strategic role in agrarian resource management. The villages with agrarian potentials, however, are currently unable to manage agrarian resources particularly land, and they tend to rely on the policies of supra-village namely: the government. This causes their agrarian and human resources to decline, which generates some important implications that the agrarian resource management needs to be reorganized, and the villagers as the principal subjects for the utilization of rural assets and resources have to participate. The agrarian resource management can be done through education, which encourages the governance of agrarian resources particularly land which rests on the villagers' participations and the changes of development paradigm from growth toward agrarian resource management. The objectives of this research are to investigate: (1) the agrarian resource management to strengthen the agrarian lives in rural areas and (2) Education of villagers for the agrarian resource management in rural areas. This research used the socio legal approach, which is the integration between the legal research and the social research. It was intended to understand the correlation and link between legal aspects and realities in the communities. The subjects of the research were the Consortium for Agrarian Reform (KPA) which has done innovations on the formation of Advanced Village of Agrarian Reform. The data of the research were analyzed by using the interactive mdole of analysis consisting of three components, namely: data reduction, data display, and conclusion drawing/verification. The result of this research could be an alternative solution to encounter the crises generated by the shrinking agrarian lives in rural areas and the escalating number of poverties among the farmers. Therefore, a strategic effort is needed as to develop the autonomy of villages with agrarian potentials toward advanced, fair, and prosperous ones through education for young generations of farmers.
\end{abstract}

\section{Keywords: Education, agrarian citizenship, villages}

\section{INTRODUCTION}

Village according to Law No. 6 of 2014, is a legal entity with borders, authorized to regulate and administer government affairs, community interests based on community initiatives, rights of origin, and / or traditional rights recognized and respected within the governance system The Unitary State of the Republic of Indonesia. Village legislation confirms that village development aims to improve the welfare of rural people and the quality of human life and poverty alleviation through the provision 
of basic needs, development of village facilities and infrastructure development of local economic potential, sustainable use of natural resources and environment.

One of the strategic issues of village law is related to the management of village assets and natural resources. This is related to the existence of a number of exploitation of agrarian resources in the village. This condition has important implications for reorganization, and the need for participation of villagers as the main subject of the utilization of village assets and resources. The management of agrarian resources as part of natural resources can be done by encouraging the reform of agrarian resource management policies based on the participation of villagers. It is important that the target and orientation of changes in the management of agrarian resources to justice, and the welfare of all citizens.

But now the villages that have the potential of agriculture that actually become the basis in fulfilling the welfare and sovereignty of the people, began to change the function of being non agrarian. Agrarian resources are no longer able to be managed according to agricultural potential. The tendency of controlling land assets as a source of agrarian to certain parties, causing injustice and gap that trigger agrarian conflicts in the countryside. The above conditions are much more natural in Indonesia's agrarianpotential villages, leading to the weakening of economic life and the loss of younger generation of farmers in the village.

A movement that is capable of shaping citizens' awareness, especially the younger generation of farmers oriented to the maintenance of agrarian resources in the village. In the opinion of Turner [13] as a theory of citizenship and social states that, in the modern era today in various countries are causing the rise of citizenship. This condition is influenced by globalization and the increasing human dependence on nature.

This condition has implications for the conception of citizenship which, according to Kalidjernih [2], raises the concept of ecological citizenship. This concept generates the movement of citizenship to protect the public from the effects of environmental damage, prevent exploitation of the environment, and encourage accountability of natural resources.

Maintenance of agrarian resources in the countryside becomes a need to be done to deal with the condition of human dependence on nature in today's global era. It takes the awareness of citizens, especially the younger generation in the countryside to maintain the agrarian resources so as not to change its potential from the agrarian characteristics. As an agricultural country has an important role in strengthening economic resilience, one of them through the productivity of agricultural life. Awareness in maintaining agrarian resources in rural areas can be realized through the approach of empowering farmers as citizens especially youth generation. The educational approach becomes an alternative solution to establish a capable citizen, "Build the Village" as an effort to organize agrarian potential agrarian resources in rural areas to a more prosperous life of all farmers.

\section{FORMULATION OF PROBLEMS}

Based on the above background, an approach is needed to create critical awareness of the citizens, especially the young generation in villages in the form of education for the management of agrarian resources through the agrarian nationality movement in rural areas. 
This research becomes alternative solution to face crisis due to the increasing loss of agrarian life, and increasing of poverty among farmers. Strategic effort is needed to build agriculture-potential village self-reliance, to a developed, fair and prosperous village.

\section{RESEARCH METHODS}

This research uses qualitative method which is also called naturalistic research. Implementation of this research occurs scientifically, what it is in a normal situation that is not manipulated circumstances or conditions, which emphasizes the description naturally. Data retrieval or phenomenon of phenomenon is done from a reasonable condition is called natural data retrieval (natural). Therefore, this study requires direct involvement of researchers [4].

The researcher was conducted in collaboration with the Jakarta Agrarian Reform Consortium (KPA), which has been innovating the formation of Maju Reforma Agrarian Village (Damara). Damara KPA will focus on fostering village areas for children, youth, farmers, women, integrative agriculture, education, democracy as a whole in its indicators.

Data analysis techniques with interactive data analysis covering three activities are done simultaneously, namely data reduction, data presentation and conclusion / verification [6]

\section{FINDINGS AND DISCUSSIONS}

\section{Management of Agrarian Resources to Strengthen Agrarian Life in Rural Areas}

Successful land management policies will be successful, if communities participate in the management of land through community empowerment in land management activities. One form of community participation in the management of agrarian resources, especially the land of Maju Reforma Agraria (DAMARA) in various villages as a form of the Agrarian Reform Consortium (KPA).

The KPA is an open and independent movement of the people's movement, aimed at advocating a just agrarian system, and ensuring equity, ownership, tenure and use of agrarian resources for farmers, fishermen and indigenous peoples, and welfare for the poor.

Damara Village KPA focuses on the village area especially on children, youth, farmers, women, integrative agriculture, education, and the realization of democracy as a whole. Education becomes an activity undertaken in Damara KPA Village, which is done through strengthening the capacity of local organizations in rural areas primarily as an effort to settle cases in areas that are in agrarian conflict. One of the villages of Damara that became the KPA built village is in Dusun Kulonbambang, Sumberurip Village, Doko District, Blitar Regency.

According to Benny Wijaya Campaign and Data Processing KPA : DAMARA is aimed at developing a system of management of village areas, especially agrarian based ones that have not been well managed. Can be caused by several factors, 
such as chronic agrarian conflicts, the absence of facilities and infrastructure supporting the economic activities of society, and the pattern of production of society that is still its own that has not been accumulated well in the form of joint ventures. DAMARA emerged in the perspective that everything available in the village, in this case the wealth of agrarian and other natural resources can be utilized as best and as widely as possible for the welfare of the villagers in this case is the farmer as majority party

According to Wibowo as a staff strengthening KPA organization, stated that the potential of agrarian life in DAMARA can run well, because the concept includes the power, order, production and consumption. In its implementation upholds the principles of agrarian, economic, gender, ecological justice sustainable. The management of land designated and utilized shall reflect the needs, cultural features and the identity of the community. In the process to ensure the use, designation and use of land through mutual agreement (participatory and consensus) among union members / communities.

Related to the condition of DAMARA in Kulonbambang, according to Nurkholipah secretary and KPA Program Manager, now has been through the process of change of power, order, distribution and consumption of farmers, among others

The change of the power of attorney, so that the people get the right to land. The people have obtained their land rights, in April 2011 with the holding of land certificates. In the program of land redistribution (landreform) Village of Kulonbambang community gets 280 hectares of land as the object of landreform.

Change of use, local communities have been encouraged to plan their collective land management, as well as effective and efficient farm management. Of the total 280 hectares, $35 \mathrm{Ha}$ is used as collective land comprising of shared land, education and training center, and other public facilities.

In the change of distribution and consumption, people have been encouraged to actively contribute to the development of cooperative economic enterprises. There has been a formation of Credit Union / CU is quite developed now.

Furthermore, according to Galih Andreanto KPA Volunteers, the area of redistribution is $280 \mathrm{Ha}, 35 \mathrm{Ha}$ for collective land, among others, joint land, education and training center of farmers and public facilities. While $25 \mathrm{Ha}$ for roads, housing / settlements, given in November 2011 and the rest for individuals but should not be sold within 10 years. DAMARA is a village that has agrarian potential, currently for its development needs to be given support, especially for market guarantee, appropriate technology, training and education.

Based on research findings in Kulonbambang; it is known that Pawartaku Farmers currently require Education / Training, Technology, Capital, Market Guarantee and Assistance. According to Yahya Zakaria Department of Advocacy and Policy of KPA, community participation becomes the main factor in Damara, because the whole process starts from the completion of the procurement, until the production system is planned and done directly by the community

The form of community participation according to Nurkholipah, currently in Kulobambang Village has been formed Paguyuban Warga Tani Kulonbambang (PAWARTAKU) which is a member of Paguyuban Petani Aryo Blitar has built a center of education and training of farmers. The farmer education and training center and collective land ownership of the proceeds are used to turn the organization on.

The management of agrarian resources is done collectively on $35 \mathrm{Ha}$ land by cultivating plants together. Once the farmer owns the land they can then establish what 
commodities they want to cultivate and manage the production that will be produced by the farmers themselves further). The determination of plant commodities is based on considerations to reduce the level of consumptive housewives in meeting their daily needs, such as vegetables. So far, farmers have not only cultivated commodities in their fields, but also thought about the processing of these commodity products for production, and distribution process. Through individual and collective owned land, the farmers take on the role of ensuring which commodities will be planted, within a certain timeframe. All mechanisms are made and the provision of support needs. With the cultivation of a commodity, the citizens can also increase their expertise to manage their own production to have added value.

The availability of land for the processing of agricultural activities becomes one of the factors related to the fulfillment of food needs. Quote from AKATIGA Foundation [5], states that "In agrarian countries like Indonesia, the main cause of poverty and lack of food is the low access of rural people to the land." Associated with the low access of citizens to the land can be known by the imbalance of land ownership in the countryside, this shows in contrast the life of the rural population between the large landowners and the majority of the poor villagers.

The existence of land is guaranteed in land law, as a form of recognition of the importance of land as part of the wealth that is shared with all the people of Indonesia. The regulation of land management is also based on the customary land law conception of "religious communalism".

According to Harsono [1], communal nature and religious character in the conception of the Law of the National Land, affirms that the land is a gift of God Almighty, so that the Indonesian people believe in God Almighty. It also contains a mandate in the form of duties to manage the land for the common interest, and maintain and maintain it as well as possible.

Referring to the principle and principle of national land management according to the National Land Agency (BPN), it is carried out with four land principles: (1) Land management should be able to contribute to the welfare of the community; (2) The management of land should be able to contribute to the justice of land ownership and ownership; (3) The management of land should be able to contribute to the sustainability of the Indonesian community and national system; (4) The management of land should be able to contribute to social harmony.

The four principles of land management mentioned above are derived from Pancasila, Article 33 Paragraph (3) of the 1945 Constitution, Article 1 through Article 15 of the Basic Agrarian Law, to strengthen the existence of land as an agrarian resource which is managed according to the spirit, And the rules contained in UUPA and the people's aspirations widely, for the greatest prosperity of the people.

The application of DAMARA is one solution to reinforce the land as an agrarian resource in an agrarian country like Indonesia. Awareness of farmers in managing the land in DAMARA is based on the principle of participative, mutual cooperation and togetherness. Citizen involvement is based on the awareness of the importance of land as part of the value of living together whose management is not only based on the individual interests of the farmers but must be able to provide benefits for all. Agricultural activities not only stop in farming, but also associated with productive economic efforts, especially for marketing agricultural products to be able to empower and prosper the peasant community. 
To strengthen agrarian life in rural areas is done through strengthening the capacity of local organizations in rural areas, especially to build a rigorous and participatory agrarian village based management system. Ensure facilities and infrastructure to support the economic activities of the community, and the pattern of community production in the form of joint ventures.

The management of agrarian resources is carried out by conducting the authority, procedures, production procedures and consumption procedures. Power of attorney, in order for the community to get land rights, while community use is encouraged to plan for collective land management, and effective and efficien management of farming. And the distribution and consumption system, the community is encouraged to actively contribute to the development of cooperative economic enterprises.

The management of land designation and utilization shall reflect the cultural, cultural and identity needs of the agrarian community. In the process to ensure the use, designation and use of land through mutual agreement (participatory and consensus) among union members / communities. For the development needs to be given support, especially Education / Training, technology, capital, market guarantees and assistance in managing land and agricultural business.

\section{Citizenship Education for the Management of Agrarian Resources in Rural Areas}

Education becomes an important thing to do to establish farmers' awareness in protecting the land as an agrarian resource. The realization of education is done related to the objectives of the agrarian reform movement that has been done since 1996.

According to Dewi Kartika, the Secretariat General (Sekjen) KPA community empowerment activities in the field of land can be done through education for farmers. It is necessary to change the perception of farmers about the importance of land for sustainable farming. Farmers not only have the right to the land, but it takes awareness to be able to manage the land in order to become a capital in fulfilling the life of farmers, especially improve their welfare.

KPA encourages the strengthening of farmers' organizations, especially their activists, to have a shared awareness of the land through special education for the activists of the agrarian reform movement with the spirit of mutual cooperation and collectivism in managing agricultural land. Education is done by building the spirit of collectivism and mutual cooperation. This movement is more emphasizing the understanding that the land must be managed together, so it is not individual anymore. Education also provides an understanding of the importance of peasant organizations, which have a collective spirit or togetherness and understanding in a generational way. Understand the land generations, not see the land is only for the interests of individuals between groups of farm families, but there is a collective spirit that is built and sustainable or sustainable.

Education is not a conventional transfer of knowledge, but uses participatory methods in a transformative framework so that everyone has equal opportunity to exchange experiences, give meaning to his experience and systematize his experience into a new knowledge system.

It is realized that the management of agrarian resources, especially land, requires an agrarian reform movement, it must be done jointly through the strengthening of 
sustainable farmer organizations to support the struggle in order to fulfill the needs of life and the strategic importance of the people.

There are three things that are formulated as the goal of education for agrarian reform, among others: (1) No discovery of significant discrepancies in the distribution of mastery, allocation and utilization of agrarian resources, commonly referred to as agrarian structures; (2) The realization of the economic system, especially the production system, which is just and able to fulfill the living needs of the developing people and able to guarantee the ecological sustainability that becomes the living space of local people; (3) The growth and development of rural folk organizations, especially peasant organizations that became the learning arena, as well as a tool for the struggle of practical needs and strategic interests of the farmers, both men and women, especially those associated with the distribution system of agricultural resources And sustainable production systems.

The education of agrarian reform movement is done by applying several topics as mentioned below: (1) The first topic on the orientation of education, which is undertaken to build the agreement of all components that participate in this special education to adhere to the orientation lines of the agrarian reform movement. The methods used are participatory, with critical thinking techniques, group discussions and idea presentations; (2) The second topic of the Agrarian question, which considers the description of the conditions of Indonesian agrarianism and the ideology of development of economic growth as a source of agrarian conflict. Methods used with critical thinking techniques and develop the theoretical concepts and context of Indonesian agrarian history; (3) The third topic on the politics of agrarian law, which conducts critical legal analysis, the identity of legal issues, and the political changes of agrarian law. The method used is participatory, through empirical, contextual, and progressive aspects, because it is associated with field experience; (4) The fourth topic on Agrarian Reform in Indonesia, analyzing agrarian reform as an integral part of rural rearrangement in Indonesia; (5) The fifth topic of discussion on the dimensions of the Agrarian Reform Movement, from its basic understanding, character, strategy and organization sourced from the initiative and power of the people; (6) The sixth topic of agrarian reform agendas, whose materials emphasize practical aspects and strategic and advocacy measures. The end of this activity is following the scenario of the development of peasant organizations, which leads to the birth of the Agrarian Reform Movement of the peasant peoples.

The education of the agrarian reform movement has relevance to the management of agrarian resources, especially land in agrarian country like Indonesia. At Durkheim menu, education can play a role in performing functions to strengthen social solidarity, maintain social roles, and maintain a division of labor.

(http://id.wikipedia.org/wiki/\%C3\%89mile_Durkheim Education as the message of the 1945 Constitution of NRIT is to create intelligent, participatory and responsible citizens in filling the life of the nation and state in order to achieve the greatness and glory of the State of Indonesia [12].

This spirit is subsequently implemented in Law Number 20 Year 2003 on National Education System, in Article 3, which states that: "National education function to develop the ability and form the character and civilization of dignified nation in order to educate the life of the nation, aiming for the development of potential learners to become human beings who believe and fear God Almighty, have noble character, 
healthy, knowledgeable, capable, creative, independent, And become a democratic and responsible citizen ".

The description asserts that education has a role to shape the character and personality of participatory and responsible citizens in democratic societies according to the objectives of the establishment of the state. According to Astim Riyanto (2009: 116), education occupies important positions and functions as the main pillar of continuity of the country.

Education for activists agrarian reform movement that has been done KPA, realized able to maintain the existence of agrarian resources, especially land. Through education aimed at joint movement of land management as agrarian resources will be realized knowledge, attitude and skills of farmers especially young generation to participate directly to do movement together. Education for the management of agrarian resources, especially land, is related to the ability to do the power, the use, the production system and the consumption order. Land management, designation and utilization will be able to reflect the needs, culture and identity as an agrarian society.

\section{CONCLUSIONS}

Villages with the potential of agriculture to be able to meet the welfare and sovereignty of the people should be able to manage the agrarian resources, especially farmers to access to land. Efforts are needed to prevent the tendency of controlling land assets as an agrarian source causing injustice and rural inequalities.

A movement that is capable of shaping citizens' awareness, especially the younger generation of farmers oriented to the maintenance of agrarian resources in the village. The management of agrarian resources should be oriented to the ability to do the power, the usage, the production system and the consumption order. Land management, designation and utilization will be able to reflect the needs, culture and identity as an agrarian society.

Education becomes a very strategic means to establish community participation in the management of agrarian resources, especially sustainable land (sustainable). Education is directed to provide an experience of the importance of living together and building the agreement of all components to undertake a joint movement. Through education will form an understanding of the problems related to agrarian resources, so it will provide the ability to solve problems. The management of agrarian resources should also be based on rural structuring efforts. Community movements that will arise because of the initiative of the whole society that originates from the common needs. It is crucial to establish a common shared awareness of strengthening the peasant organization, which will be a common tool in the management of agrarian resources.

\section{REFERENCES}

[1] Harsono, Boedi. (1997). Hukum Agraria Indonesia. Jakarta : Djambatan.

[2] Kalidjernih, F.K. (2010). Puspa Ragam, Konsep Dan Isu Kewarganegaraan. Bandung : Widya Aksara Press.

[3] Limbong, Bernhard. (2012). Konflik Pertanahan. Jakarta : Margaretha Pustaka.

[4] Lincoln, YS and Guba. (1985). Naturalistic Inquiry. Beverly Hills CA : Sage Publication Ins. 
[5] Maguantara, Y.N, ed. (2005). Ayo Wujudkan Kedaulatan Atas Pangan : Panduan dan Modul Pendidikan untuk Aksi Pembaruan Sistem Pangan Komunitas Desa. Bandung : AKATIGA dan KRKP.

[6] Miles, Matthew B. and Huberman, A Micheal. (1984). Qualitative Data Analysis, A Sourcebook of New Methods. Beverlly Hills CA : Sage Publications, Inc.

[7] Republik Indonesia. Undang-Undang Dasar Tahun 1945

[8] Republik Indonesia. Undang-Undang Nomor 5 Tahum 1960 tentang Peraturan Dasar Pokok-Pokok Agraria

[9] Republik Indonesia. Undang-Undang No. 20 Tahun 2003 tentang Sistem Pendidikan Nasional

[10] Republik Indonesia.Undang-Undang Nomor 6 Tahun 2014 Tentang Desa

[11] Riyanto. Astim. (2009). Kapita Selekta Hukum Konstitusi. Bandung: YAPEMDO

[12] Sapriya. (2007). Perspektif Pemikiran Pakar Tentang Pendidikan Kewarganegaraan dalam Pembangunan

Karakter Bangsa (Sebuah Kajian Konseptual-Filofis PKn dalam Konteks Pendidikan IPS). Disertasi SPs

UPI, Bandung.

[13] Turner, B.S. (eds). (1993). Citizenship and Social Theory. London : SAGE Publication. 